\title{
Norois
}

Environnement, aménagement, société

\section{Negotiating and Remembering the End of the World: Insights into Ancient People's Responses to Sea-Level Rise}

"Négocier " et se souvenir de la fin du monde: des aperçus des réponses des anciens habitants des côtes à la remontée du niveau des mers

Patrick D. Nunn

\section{OpenEdition}

\section{Journals}

\section{Electronic version}

URL: https://journals.openedition.org/norois/9108

DOI: $10.4000 /$ norois. 9108

ISSN: $1760-8546$

Publisher

Presses universitaires de Rennes

\section{Printed version}

Date of publication: 22 November 2019

Number of pages: $15-26$

ISBN: 978-2-7535-7875-3

ISSN: 0029-182X

\section{Electronic reference}

Patrick D. Nunn, "Negotiating and Remembering the End of the World: Insights into Ancient People's Responses to Sea-Level Rise", Norois [Online], 251 | 2019, Online since 02 January 2022, connection on 06 January 2022. URL: http://journals.openedition.org/norois/9108 ; DOI: https://doi.org/10.4000/ norois.9108 


$F$ Nö́rels

\title{
Negotiating and Remembering the End of the World: Insights into Ancient People's Responses to Sea-Level Rise
}

\author{
«Négocier » et se souvenir de la fin du monde : des aperçus des réponses \\ des anciens habitants des côtes à la remontée du niveau des mers
}

\author{
Patrick D. NunN
}

Professor of Geography, School of Social Sciences / Indigenous Studies Research Theme, University of the Sunshine Coast, Queensland 4556, Australia (pnunn@usc.edu.au)

\begin{abstract}
At the end of the last ice age (Last Glaciation) when vast land-based ice sheets melted, water poured into the ocean causing the sea level to rise 120 metres 15,000-6,000 years ago. For many coastal dwellers, this sea-level rise must have been calamitous, perhaps perceived as the end of the world. A key question is how people responded to this threat. Did they accept it or did they actively resist it and try to halt its progress? Insights from traditional stories in long-standing cultures in Australia, France and India suggest people not only recognised the threat from continuing sea-level rise but also that they sought various ways of stopping it. Two approaches to negotiating the challenge of rising sea level are identified - the spiritual and the practical. Spiritual practices appear probable but are difficult to elucidate because of an incomplete understanding of their material and societal context. Practical solutions are better understood, largely because of information in ancient stories. Some Aboriginal Australian stories explain practical measures taken by people, presumably more than 7,000 years ago, that include tossing hot rocks into the encroaching ocean and building wooden fences along the shoreline. Details in stories from France and India that recall times when coastal cities (like Ys in Brittany and Kusasthali-Dwaraka in northwest India) were submerged can help reconstruct a plausible narrative describing the interaction between sea-level rise and coastal settlements. It seems likely that stories about such settlements affected by sea-level rise recall times when they were significantly rebuilt with the intention of sustaining their functionality but that they were eventually overwhelmed by sea-level rise, their existence passing into the realm of legend.

Modern coastal dwellers are threatened by sea-level rise. Understanding how this affected their ancestors can help overcome scepticism and a sense of helplessness and aid in the development and implementation of realistic adaptive strategies.
\end{abstract}

Résumé : À la fin de la dernière ère glaciaire, lorsque fondirent les couches de glace recouvrant les vastes plateformes continentales, les eaux qui se déversèrent dans les océans provoquèrent la remontée des niveaux marins entre 15000 et 6000 ans BP. Pour la plupart des habitants des zones côtières cette remontée des eaux dût être désastreuse, au point peut-être d'être perçue comme la fin du monde. Une question cruciale est donc celle de savoir comment ces gens répondirent à cette menace. L'acceptèrent-ils ou y résistèrent-ils de façon active en essayant d'arrêter le processus? Des aperçus à partir de récits traditionnels de cultures millénaires d'Australie, France et Inde suggèrent que ces populations non seulement reconnurent la menace représentée par la remontée continue du niveau des mers, mais cherchèrent aussi à l'arrêter de différentes manières.

Deux différentes approches pour faire face au défi de la remontée des eaux des mers peuvent être identifiées, l'une de nature religieuse, l'autre de type opérationnel. Des pratiques rituelles semblent probables, mais elles sont difficiles à identifier en raison de connaissances insuffisantes sur leur contexte matériel et sociétal. Des solutions pratiques nous sont mieux compréhensibles, grâce notamment aux informations tirées des anciennes légendes. En effet, des récits des Aborigènes australiens nous font connaître certaines mesures pratiques adoptées par ces populations, vraisemblablement il y a plus de 7000 ans, telles que lancer des rochers brûlants dans l'océan envahissant la côte ou construire des clôtures en bois le long du rivage. Certains détails de légendes françaises ou indiennes qui rappellent l'époque où des villes 
côtières (comme Ys en Bretagne et Kusasthali-Dwaraka dans le nord-ouest de l'Inde) furent submergées peuvent aider à reconstruire un cadre narratif plausible des interactions entre la remontée des eaux et le sort des établissements côtiers. Il semble probable que de telles histoires sur des villes qui subissent les effets de la remontée des océans rappellent une époque où des sites côtiers furent reconstruits en grande partie afin de maintenir leurs fonctions essentielles, mais qu'au final ils furent visiblement submergés, le souvenir de leur existence devenant matière de légendes.

Les habitants des zones côtières d'aujourd'hui craignent la remontée des eaux des mers. Comprendre de quelle façon le même phénomène affecta leurs ancêtres peut aider à dépasser des réactions de scepticisme et un certain sens de fatalisme, contribuant à développer et à mettre en ceuvre des stratégies adaptatives réalistes.

Keywords: Risk - Sea-level - ancient stories - Holocene - climate change - adaptation - perception

Mots clés : Risque - niveau marin - légendes - Holocène - changement climatique - adaptation-perception

\section{BACKGROUND}

At the end of the last ice age, about 15-18,000 years ago, the ice that had built up on the continents began to melt. The meltwater produced poured into the world's oceans, raising its surface level some 120 metres in the next 8000-15,000 years. What must people living along the world's coasts have thought about this sea-level rise? How did rising sea level change the way coastal peoples lived? And did these people absorb these changes passively or did they resist them? There is now enough information available to provide answers to these questions that are reasonably convincing, at least for some parts of the earth's surface. This information is instructive in that it allows us today to understand better how our distant ancestors viewed and responded to environmental change. It also allows us to understand how ancient memories of the effects of environmental change on the ways that people once lived might help people today to understand and cope with future environmental change.

This paper focuses on the effects of sea-level rise, perhaps the most profound threat to coastal people's livelihoods that they can imagine, particularly in coastal subsistence communities but also in coastal cities. Sea-level rise involves the steady loss of coastal land, land that is important not only for providing the foods that sustain coastal people (and allow them to trade with people elsewhere) but also for providing them with a place to live. Remove place, remove the means of sustenance, and you undermine identity, and often force profound societal change. This was as much a reality in the past as it is today (Day et al., 2007).
Sea level changes regularly; coastal people are well adjusted to its short-term (tidal) changes and also accustomed to periodically absorbing wave extremes but far less adept at recognising and adapting to slower, more prolonged changes of sea level (Mimura, 2013, Bennett et al., 2014). Over the past two hundred years along most of the world's coasts, sea level has been rising slowly while at the same time coastal populations have grown comparatively rapidly. Many coastal dwellers today feel a sense of entitlement; they believe they have the right to occupy the coast, they consider that they and their ancestors have done so indefinitely, and they vigorously reject any suggestion that coasts are changing and that they may not be able to remain living where they are ten years hence. This applies as much to people living along coasts in richer ('developed') countries as to those in poorer ('developing') countries. Knowledge about how earlier generations of coastal dwellers in such places can help ease conversations about the need to relocate vulnerable coastal settlements and infrastructure in the future (Janif et al., 2016).

\section{Negotiating THE END OF THE WORLD}

Today, some people have become so concerned about future climate change, so convinced that humanity is unable to find a 'solution' to it, that they consider it foreshadows the 'end of the world' (Barker and Bearce, 2013, Buchs et al., 2015). In the 1960s, the development of nuclear weapons that could destroy the entire planet led to the development of similar millennialist attitudes and is still reflected in the contemporary proliferation of well- 
provisioned underground shelters where the lucky few might survive the aftermath of nuclear warfare (Wojcik, 1996, Ziauddin, 2017). Go back ten thousand years or so and it is possible that similarly fatalistic feelings were engendered by sea-level rise. Let us consider a few examples.

At some points during the period of postglacial sea-level rise, sea level rose faster than at others. Consider that after the proglacial Lake AgassizOjibway breached its ice dam in Hudson Bay 8200 years ago, there may have been an almost instantaneous rise of sea level in the Gulf of Mexico of 1.2 metres (Tornqvist et al., 2004); the Mississippi Delta of the time would have been flooded, perhaps thousands of its human residents abruptly displaced. And when rising sea level in the Mediterranean finally pushed water along the Bosporus into the Black Sea Basin, the thousands of agriculturalists living there may have been forced out in a matter of weeks, perhaps initiating the Neolithic Transition that saw the rapid spread of agriculture across Europe (Turney and Brown, 2007, Bruckner et al., 2010); did the memory of this displacement inform the stories of great floods in the Epic of Gilgamesh and become fused with Christian teachings in the Book of Genesis? And in northern Australia, when the shoreline was moving landwards at a rate of five kilometres each year, as it did at some times (Flood, 2006), how did human observers rationalise what they saw was happening? Did they suppose that the sea level would continue rising until it engulfed all the land in the world? The innate tendency of humans towards eschatological belief suggests that in all these cases - the southern USA, the Black Sea, and northern Australia - it is plausible to suppose that the rationalisation of observed sea-level rise included the view that this was unstoppable and threatened the very existence of humanity, a suggestion that receives corroboration from the innumerable 'world-flood' myths found in almost every longenduring culture (Dundes, 1988, Huggett, 1989).

The first part of this paper is concerned with how people in the distant past responded to the threats from sea-level rise - and how we might best interpret these responses. This is what I mean by 'negotiating' the end of the world. Today, humanity is using science to negotiate its way out of climatechange calamity, just as thirty years ago a negotiated end of the Cold War signalled a downscaling of the threat of nuclear war. It might be said that while the majority despairs in such situations, their leaders eventually rise to the challenges required to cope with them. The minutiae aside, let us suppose the same situation obtained in the distant past and that leaders eventually emerged who successfully rationalised to the people they led what sea-level rise meant and what they should do to address it. Of course, the context was different. No one 6,000 years and more ago lived in a globalised world as we do today; no leader at that time commanded the millions of peoples that some do today. Yet, as the following stories demonstrate, people recognised the challenges posed by rising sea level and appear to have responded collectively.

Perhaps the most widespread responses required the incorporation of sea-level rise (as an environmental threat) within people's spiritual belief systems (Cassen, 2009, Cassen et al., 2018). It seems likely that various ethnographically-recorded practices, such as volcano 'worship' and place-avoidance behaviours, originated in response to people's rationalisation of particular types of risk. Volcano worship remains common, especially in southeast Asia (Schlehe, 2008), and involves the routine offering of gifts to the intransigent 'gods' within volcanoes who it is believed can be entreated not to direct eruptions towards particular places. Place avoidance seems likely to have once been more common - there is evidence of such practices in the northwest USA that date back more than seven thousand years (Barber and Barber, 2004) - and arose when people believed that by avoiding sacred ground, the abode of gods, their wrath could also be avoided.

Another example would be when people in resource-constrained environments were affected by prolonged (multi-generational) droughts or cold periods, for example, and devised ways of supplication intended to persuade the gods to relieve their hardship. The example of the moai (stone statues) on Easter Island, one of the most isolated and droughtprone islands in the Pacific, is a good illustration; the human effort involved in the carving, transport and erection of these massive statues can be seen as a measure of the climate-forced desperation in which the people of Easter Island found themselves in the $14^{\text {th }}$ century (Haberle and Chepstow-Lusty, 2000). However impractical we might today regard such responses to environmental stress, it should be 
remembered that at the time they probably made perfect sense and were perceived as optimal.

Yet people in the past also developed more practical responses to such changes. Consider how many people once responded to earthquakes. In Tonga and parts of India, following an earth tremor, people would come out of their houses making as much noise as they could; in the former to rouse the god believed to be holding the island upright who was thought to be nodding off to sleep (Lawry, 1850); in the latter, to assure the people living within the earth that their relatives on its surface were still alive - and wanted to remain so (Vitaliano, 1973). While we may today regard such responses as anthropological curiosities, we should remember that in the past these were undoubtedly regarded as effective ways of preventing the escalation of environmental stress (Severn, 2012).

Practical responses in the distant past to sea-level rise, which can also be explained (or accelerated) by land sinking (subsidence), are less well known. Perhaps this is because such responses were rendered useless comparatively quickly. Consider, for example, that volcano worship is a practically timeless response to volcanic activity, for whenever there is an eruption that affected the worshippers badly, it can always be claimed that they lapsed in their obligations to the volcano gods and were punished in consequence. Yet with sea-level rise, once a particular line of defence has been crossed, then the solution proposed is instantly exposed as worthless and another solution needs to be sought. In Australia, where Aboriginal stories have been shown to be more than seven millennia old (Nunn and Reid, 2016), there are some recollections about how people responded to postglacial sea-level rise which here, unlike some of the coasts of Europe, ceased about 5,000-6,000 years ago (Lewis et al., 2013).

During the coldest time of the last ice age - the Last Glacial Maximum (22,000-18,000 years ago) the sea level reached a minimum, about 120 metres below its present level. Australia was joined to New Guinea by a land bridge; the entire land mass was about $26 \%$ larger than it is today (figure 1 - plate I). In the period $15,000-7,000$ years ago, this $26 \%$ was submerged, leading to the creation of stories that have reached us today (Nunn and Reid, 2016). The existence of these stories, in at least twenty-one locations all along the Australian coast, shows that Aboriginal people witnessed the effects of postglacial sea-level rise here. There are two stories about how they tried to stop rising sea level.

The Gungganyji Aboriginal people of the Cairns area, where "many tribes... have stories recounting how the shore-line was once some miles further out ... where the barrier reef now stands" (Dixon, 1980: p. 46), blame a person named Goonyah for the sealevel rise there. Yet they recall he was also instrumental in trying to stop it. In one story, to escape sea-level rise, he led his tribe up a mountain where they made a huge fire and heated rocks that they rolled down the mountain side and "succeeded in checking the flood” (Gribble, 1932, p. 56-57).

In the south of Australia, where the desert formed by the Nullarbor Plains meets the ocean in a line of impressive cliffs, there is a story about how once much of the ocean floor was once dry land (as indeed it was during the last ice age). A perverse old man went through the desert uprooting mallee eucalypt (water-bearing) trees causing the sea to rush in across the dry land below the cliffs. Fearing the land would be submerged, the Aboriginal people of the Nullarbor - the Wati Nyiinyii - raced to the bottom of the cliffs and when they reached the sea, "they begin bundling thousands of spears to stop the encroaching water ... these bundles were stacked very high and managed to contain the water" at the base of the cliffs (Cane, 2002, p. 91).

From the existence of such stories about how ancient Aboriginal Australians once tried to halt the progress of postglacial sea-level rise, it is clear that this was a phenomenon which was actively resisted - and by inference undesired - by Australia's contemporary inhabitants. This in turn gives us unique insights into how such people must have perceived such environmental threats.

It also seems likely, although the evidence is understandably far more diffuse, that ancient Aboriginal Australians created spiritual responses to sea-level rise that were also intended - like the heated rocks and the spear fences - to stop the sealevel rise they feared. For instance, along the north Australian coast at low tide can be seen stone arrangements that may be "associated with ritual control of extreme tidal regimes” (McNiven, 2008, p. 155).

Additional insights into ancient Australian Aboriginal attitudes towards sea-level rise can be 
Figure 1: Map of Australia and New Guinea showing the extent of the dry land (Sahul) during the Last Glacial Maximum about 22-18,000 years ago when sea level was about 120 metres lower than today. Places named in the text are also shown together with the recently-active volcanoes of Muirhead and Schank.

Carte de l'Australie et de la Nouvelle Guinée montrant l'extension des terres émergées lors $d u$ dernier maximum glaciaire, il y a environ 2200018000 ans, alors que le niveau de la mer était d'environ 120 mètres inférieur au niveau actuel. Les localités mentionnées dans le texte y figurent ainsi que les volcans de Muirhead et Schank actifs depuis une époque récente.

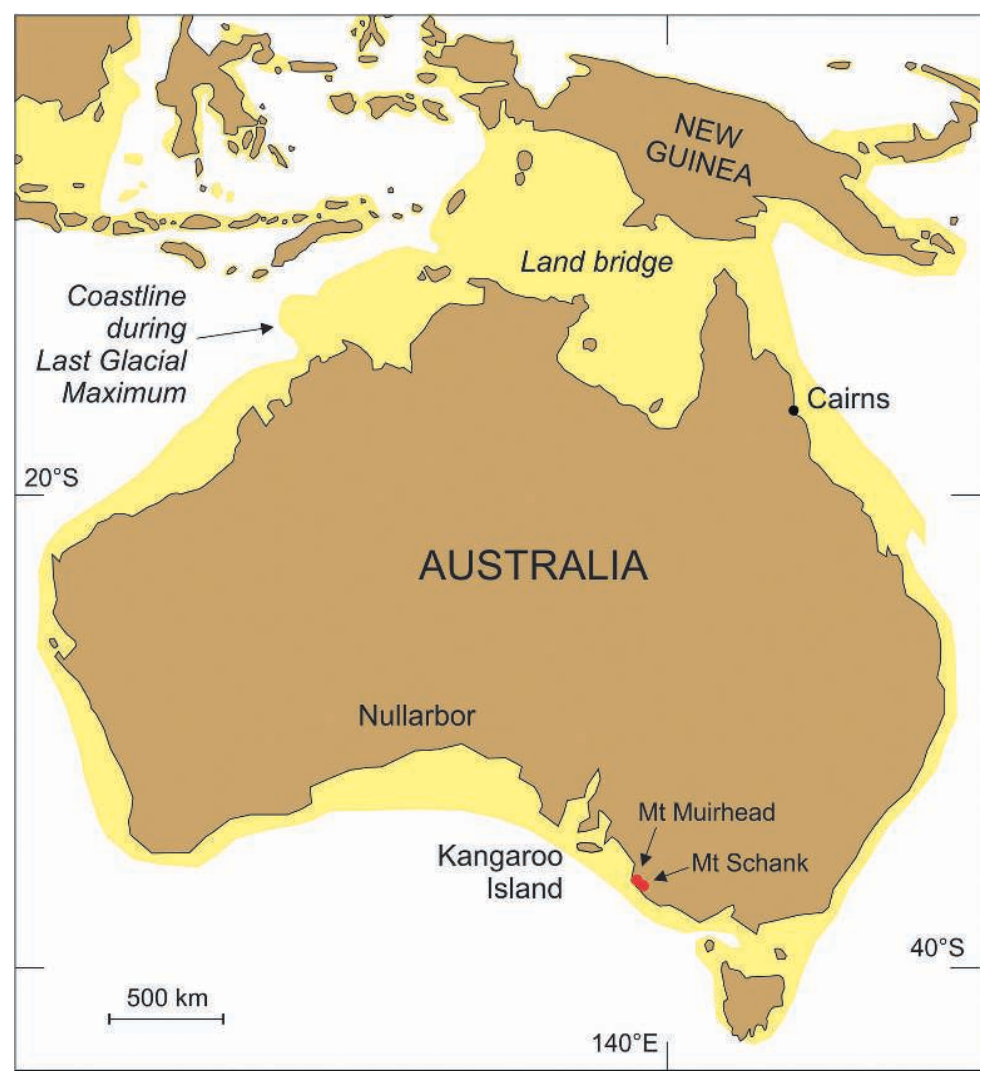

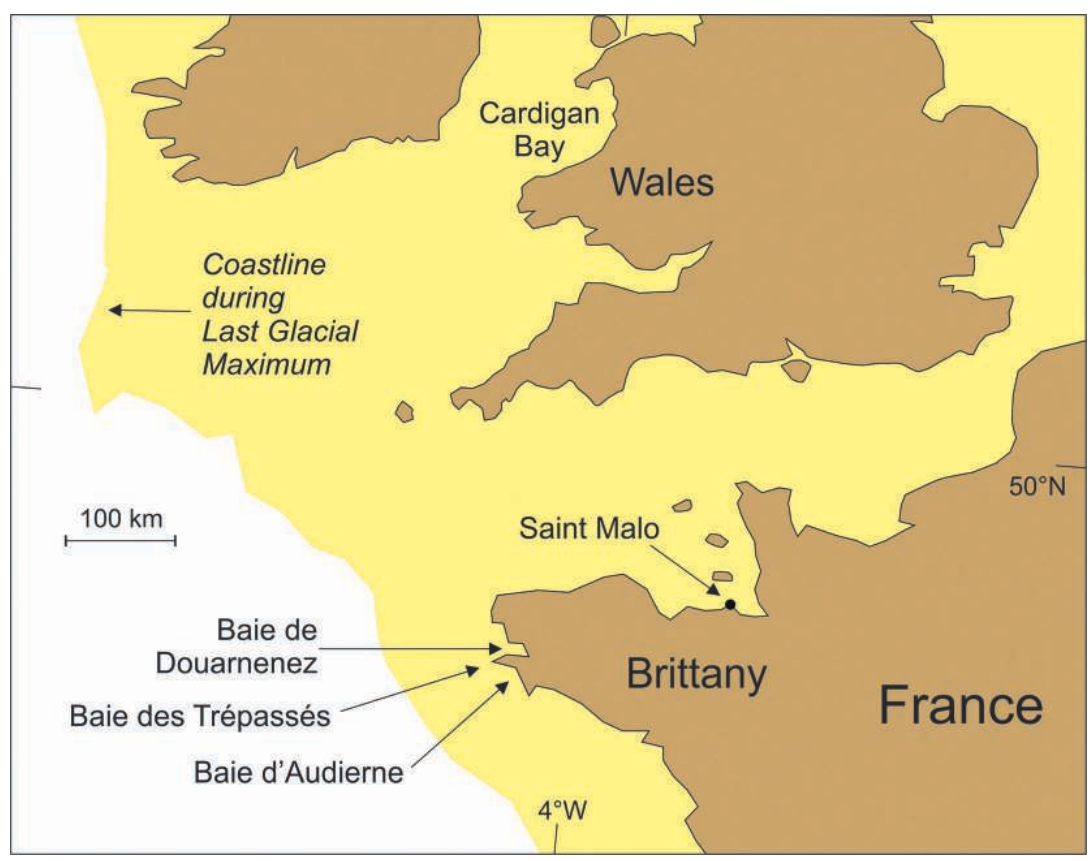

Figure 2: Map of part of Northwest Europe showing the extent of the dry land during the Last Glacial Maximum. Places named in the text and referred to in Figure 3 are shown.

Carte d'une partie de l'Europe nord-occidentale, montrant l'extension des terres émergées lors du dernier maximum glaciaire. Les localités mentionnées dans le texte et qui apparaissent aussi sur la Figure 3 $y$ figurent. 


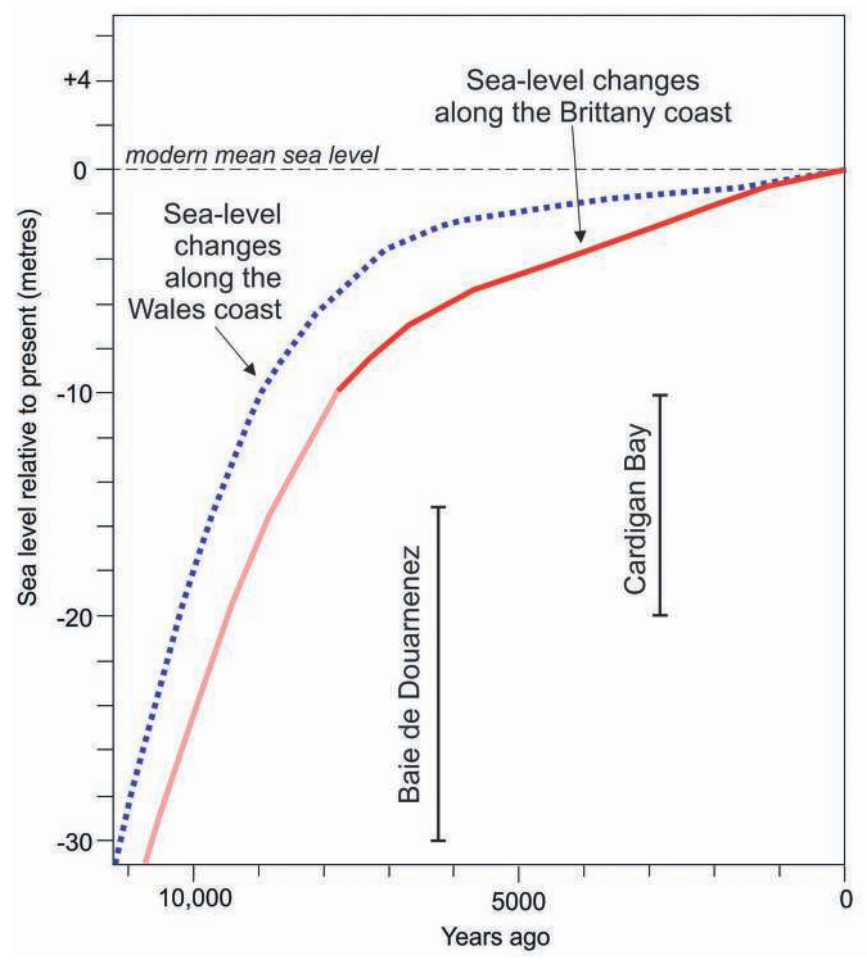

Figure 3: Sea-level curves for the past 10,000 years for Brittany (Goslin et al., 2015) and Wales (Roberts et al., 2011); note that the Brittany curve is based on empirical data until about 8,000 years ago and extrapolated further back in time. In both cases, sea level has been rising since around the end of the Last Glaciation about 15,000 years ago. Reconstruction of depths where Ys may have been located in the Baie de Douarnenez and where Cantre'r Gwaelod may have been located in Cardigan Bay allow crude minimum ages for these stories to be calculated. Figure adapted from Nunn (2018b).

Courbes des variations des niveaux de la mer depuis les 10000 dernières années en Bretagne (Goslin et al., 2015) et au Pays de Galles (Roberts et al., 2011) ; à noter que la courbe pour la Bretagne a été construite à partir de données empiriques de terrain jusqu'à il y a 8000 ans, alors qu'il s'agit d'une estimation pour la période antérieure. Aussi bien en Bretagne qu'au Pays de Galles la remontée du niveau des mers est constante depuis la fin de la dernière époque glaciaire il y a environ 15000 ans. La reconstitution de la profondeur à laquelle il faudrait situer la ville d'Ys dans la baie de Douarnenez et du possible emplacement de Cantre'r Gwaelod dans la baie de Cardigan permet d'avancer un âge minimum pour une datation grossière de ces légendes. Figure adaptée d'après Nunn (2018).

Figure 4: Sea-level curve for the past $\sim 9,000$ years for India, synthesised from that for Malaysia (Woodroffe and Horton, 2005), Singapore (Bird et al., 2007) and the Maldives (Kench et al., 2009). The sea surface reached its present level about 7,000 years ago and then exhibited comparatively minor fluctuations since then. Probable ages for the existence of ancient Kusasthali-Dwaraka are represented by the solid bar. If it is assumed that submergence occurred at times of rising sea level, then it is possible that Kusasthali began to be submerged more around 5,200 years ago while its successor, Dwaraka, was submerged about 2,350 years ago. Figure adapted from Nunn (2018b).

Courbe des variations du niveau de la mer depuis les 9000 dernières années en Inde, reconstituée à partir de celles de la Malaisie (Woodroffe and Horton, 2005), de Singapore (Bird et al., 2007) et des Maldives (Kench et al., 2009). La mer avait déjà atteint le niveau actuel il y a environ 7000 ans et depuis cette date celui-ci connaît des fluctuations relativement mineures. Les datations possibles pour l'existence de l'ancienne Kusasthali-Dwaraka sont représentées par la barre noire. Si l'on admet l'hypothèse que la submersion s'est produite à l'époque de la remontée du niveau de la mer, il est alors possible que le site de Kusasthali commença à être submergé il y a plus de 5200 ans, alors que la ville qui lui a succédé, Dwaraka, fut submergée il y a 2350 ans environ. Figure adaptée d'après Nunn

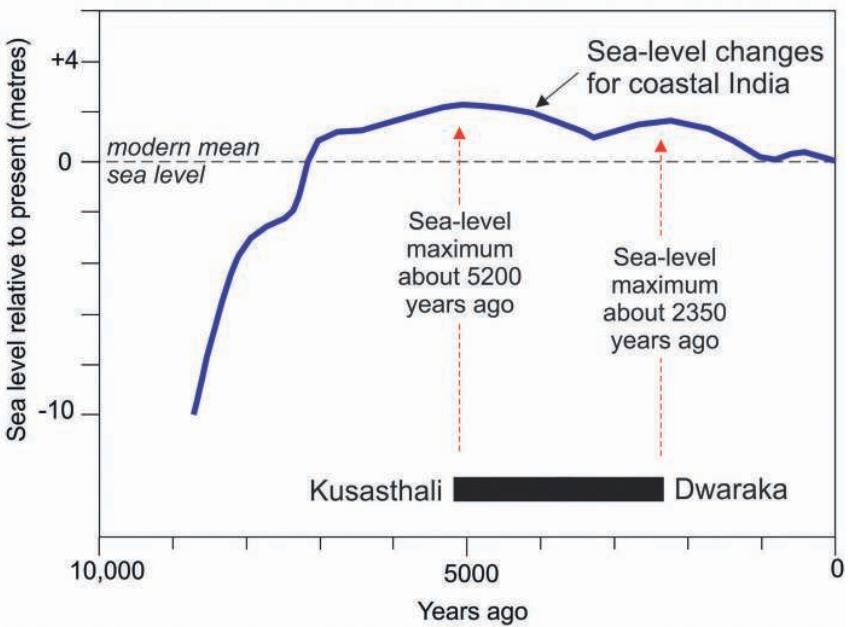
(2018). 
inferred from the occupation history of offshore islands in Australia (Sim and West, 1998, Rowland et al., 2015). At the time of European discovery and settlement of Australia in the late $18^{\text {th }}$ century, most smaller offshore islands were uninhabited yet showed signs of once having been otherwise. Studies of Australian island archaeology suggest that in some cases people intentionally abandoned these (often resource-poor) islands shortly after their land connections with mainland Australia were submerged by rising sea level. It has been suggested that the islanders realised that sea level was continuing to rise and that, if they stayed where they were, they were likely to become increasingly isolated from mainland people and resources. Yet it is also inferred from Kangaroo Island, one of the largest of these so-called 'mystery' islands, that some people elected to stay on the island after the land connection with the mainland was severed; it seems likely that a prolonged drought led to their extirpation (Draper, 2015).

Comparable responses to Holocene sea-level rise are known from northwest France where there exist a number of Neolithic stone rows - made from parallel lines of largely regularly-spaced steles. Explanations for these stone rows requiring particular astronomical alignments, or functioning as temples or graveyards have all been found wanting. A more recent interpretation, based on careful analyses of the geometry of these stone rows - above and below present sea level - is that they represent a 'cognitive barrier' rather than having any tangible functionality (Cassen, 2009). Specifically it is proposed that vertical steles of this kind were regarded in Neolithic times here as "a symbolic threshold between two dimensions" (Cassen et al., 2011 , p. 100) that prevented movement between the physical and other worlds. A link between these stone rows - as well as the location of the historiated stele at Saint-Samson-sur-Rance (Cassen et al., 2018) - and sea-level rise is plausible. Specifically, these stone rows have been interpreted as having been built as resistance to rising sea levels in this area, likely around 6,250 years BP (4,300 BC) when the rate of sea-level here accelerated (Baltzer et al., 2015).

\section{REMEMBERING THE END OF THE WORLD}

In pre-literate societies, the only way to pass important information on from one generation to the next was orally. While this may have been supplemented by song, dance, performance and even (rock-) art, oral communication was paramount and became an effective method of trans-generational knowledge transfer, especially among people living - like Aboriginal Australians - in resourceconstrained environments. In many oral traditions, knowledge about environmental risk and the ways the ancestors coped with this was often considered some of the most important information to pass on to younger people. It was essential for their survival should the same risk present itself again in the future. Such oral traditions are the equivalent of today's protocols for managing similar risk, from earthquakes and volcanic eruptions to extreme waves (tsunamis), floods and strong-wind events.

In the past, there were times when it must have seemed to people in particular places that the end of their world was imminent. Perhaps nowhere was this more marked than when that world was isolated, as with an island in the middle of a vast ocean, the threats of extinction exaggerated by geography? This has been used to explain why Pacific Island societies evolved cultural protocols like abortion and infanticide to cope with resource depletion (McNeill, 1994); one of the more evocative practices for coping was 'suicide voyages' in which canoes full of people might set sail from island shores knowing full well they would never return or find land elsewhere (Currey, 1980, Nunn, 2007).

A more common scenario along continental coasts and among more complex societies may have involved the construction of coastal settlements, later followed by the construction of sea defences (as sea level rose), and finally by the abandonment of the site as the rising ocean submerged it. This scenario is illustrated by two case studies, one from Brittany (France), the other from the west coast of India. In the former location, sea level appears to have been rising almost continuously since the end of the Last Glacial Maximum, a situation that contrasts with most other coasts of the world (like those in Australia and India) where postglacial sealevel rise ended about 6,000 years ago. 
There are persistent stories in Breton culture (and others nearby) about the city of Ys (Ker-Ys) that once existed off the modern coast of Brittany (figure 2- plate II), commonly placed in the Baie de Douarnenez but sometimes in the Baie des Trépassés or Baie d'Audierne (Guyot, 1979); one account places Ys off the coast of Saint Malo (Sébillot, 1899). While there are many variations to the legend, the gist is that Ys was the seat of King Gradlon whose daughter Dahut - either wilfully or while bewitched - opened the flood gates one night allowing the ocean to enter the city, after which it became uninhabitable, abandoned, and eventually consigned to the realm of legend. All stories about Ys (and similar) from the region report that it was a city that had been built (or adapted) to prevent it from being flooded by the sea; similar stories surround the nature of the legendary city of Cantre'r Gwaelod in Cardigan Bay (Wales) (Doan, 1981, Nunn, 2018a).

We need not take modern stories like that of Ys or Cantre'r Gwaelod literally in order to recognise them as narrative legacies of a time when sea-level rise did in face "drown" coastal settlements. The argument in favour of this is that Brittany has been inhabited for 10,000 years and more; stories can clearly endure this long in other contexts; the sea level has been rising for most of this time, so why should there not be Breton stories that are based on fragmented memories of places that were "drowned" long ago? There is an abundance of places along the coasts of Brittany and Normandy where there are such "drowned" places (Billard et al., 2016).

Comparable stories also define memories of the city of Dwaraka (Dvaraka or Dwarka) on the western side of the Saurashtra Peninsula in northwest India. Celebrated in the Mahabharata and other ancient texts as the abode of Lord Krishna, Dwaraka (the Golden City) is also said to have been a coastal city with elaborate sea defences that was one day overwhelmed by the sea, abandoned, and its reality forgotten. The parallels with Ys (and Cantre'r Gwaelod) are striking - and can be explained by the progressive effects of sea-level rise along these coasts, as described below.

Go back several millennia, imagine why a settlement might be established along the coast. Trade might have been the main reason, sea transport at the time being far faster and more reliable than land transport. In northwest Europe, harbour settlement along the west coast of Brittany would have been ideally positioned to receive shipping from northern Europe (especially the British Isles). Similarly in northwest India, a city in coastal Saurashtra would have been well located to act as a focus for trade between Arab peoples to the west and those of continental India, particularly the Gangetic cultures to the east. Establishing a settlement close to a river mouth, perhaps on a hill, perhaps around a natural harbour, would have been favoured. But a few hundred years after the settlement was established, as a result of sea-level rise (perhaps amplified by subsidence) and river-channel siltation, its functionality began to be diminished. Perhaps the lower parts of the site were becoming regularly inundated by the ocean; perhaps the entire settlement was becoming increasingly cut off from its hinterland. What happened next?

Perhaps a visionary leader - Gradlon of Ys or Krishna of Dwaraka - decided to try and revive the settlement's fortunes though a massive engineering project, intended to keep the ocean out and restore the site's functionality as a port and as an iconic location for the people of the respective regions. These engineering works may have involved the construction of flood gates, to be closed as the tide was rising and opened when it was low, and the building of raised causeways to connect the settlement to the hinterland. Both these details are common in several versions of the stories about Ys and Cantre'r Gwaelod in northwest Europe (Nunn, 2018a). In the case of Dwaraka, there is evidence that an earlier town (Kusasthali) existed on the site before Lord Krishna arrived and began an elaborate programme of land reclamation and port infrastructure construction. It seems likely that the original city of Kusasthali, perhaps part of the later Harappan culture, became increasingly prone to sea flooding until a new leader - Lord Krishna - planned and undertook a major reconstruction of the town that was renamed Dwaraka. Perhaps just a few generations later, Dwaraka succumbed to the rising sea; it was progressively abandoned as the ocean invaded the city. Similarly, after the night when the flood gates were opened at Ys (and at Cantre'r Gwaelod), the site appears never again to have been reoccupied.

While the abandonment of such settlements is invariably portrayed as abrupt - a result of a shortonset event - the reality is likely to be different. This 
is because human memories, especially when transmitted orally, are often subject to 'memory crunch' (in which details are conflated) and exaggerated to make stories more memorable (Barber and Barber, 2004). It seems more likely that, just like today, extreme-wave events (like storm surges or tsunamis) at these locations were superimposed on progressive sea-level rise; people remember the extreme events, overlooking the less-memorable background changes that rendered extreme events of the same magnitude increasingly damaging. And so stories about the abandonment of coastal cities are often linked to extreme-wave events, even though the reality was probably more mundane.

The fact that no-one today is certain where the 'drowned' cities of Ys (and Cantre'r Gwaelod) and Dwaraka actually were suggests that so much time has elapsed since they 'disappeared' that memories and associations have faded and now survive only by virtue of being attached to other stories - like those of the culture heroes King Gradlon and Lord Krishna. This makes the question of when these 'cities' existed difficult to answer. One approach, developed for Australian Aboriginal drowning stories (Nunn and Reid, 2016), is to identify the likeliest locations of these settlements and then estimate how much lower than today the sea level would need to be for these locations to be those where a functioning coastal (port) settlement might exist. It is then simply a matter of consulting data on postglacial sea-level change for these locations and estimating how many years ago the sea level was where it is estimated to have been (Nunn, 2018a). Using this approach, it can be estimated that, if the 'city' of Ys existed one kilometre or so off the modern coast of the Baie de Douarnenez, its ruins now lie 15-30 metres below sea level. According to the sea-level curve for this part of the French coast, sea level was last at this level 8,750-10,650 years ago which is a minimum age (using this method) for the stories about Ys (figure 3 - plate II). Of course there are a lot of assumptions behind this calculation and it would be foolish to insist it was indisputable yet it is one way of dating such stories. Using a similar approach, stories about KusasthaliDwaraka might date from 2,350->5,200 years ago (figure 4 - plate II).

Just as in many coastal cities today that are threatened by rising sea level (Jacob, 2015), so with Ys and Dwaraka during the latter decades of their active existence, their inhabitants must have felt increasing levels of anxiety. It is therefore understandable that they welcomed the strong leadership from King Gradlon and Lord Krishna and supported their efforts to protect the cities. But the end came inevitably, the sites were abandoned, submerged and substitutes created as the memories of the originals became gradually confined to old stories and eventually to legends. Yet what is clear is that, just as with the attempts of ancient Aboriginal Australians to halt the progress of sea-level rise (see above), so the people of Ys and Dwaraka appeared determined to resist the threats to their way of life from the rising sea level. The fact that they eventually failed is largely immaterial; it is the likelihood that they resisted which gives us insights into the ways in which our distant ancestors regarded environmental risk. It may have appeared that the end of the world was approaching but people were not passively accepting of this.

\section{Conclusion}

Sea level has been rising for more than a century - it rose an average $19 \mathrm{~cm}$ between 1901 and 2010 (Church et al., 2013) - and, since 1993, its rate has accelerated to an average $3.1 \mathrm{~mm} /$ year (Dangendorf et al., 2017). Science-informed projections for the future suggest sea level is likely to be around $88-190 \mathrm{~cm}$ higher in the year 2100 than it was on average in 1985-2005 (Church et al., 2013, Jevrejeva et al., 2014). There is a scientific consensus that humanity is less than optimally prepared to cope with the effects of sea-level rise this century and beyond, effects that will be profound and exacerbated by other aspects of climate change and increased human demands on natural resources (IPCC, 2014).

Coastal-dwelling people are especially vulnerable to sea-level rise, as are those living on extensive coastal lowlands such as in the large river deltas. Understanding the likely nature of future environmental changes in such places - and overcoming the inevitable scepticism - can be aided by teaching people about what happened in the past, specifically how their ancestors coped with the effects of similar sea-level rise. Particularly in subsistence-based societies, this approach can tap into deep-rooted 
cultural resilience that is recognised as an essential ingredient in any adaptive strategy. For example, it has recently been shown that people in the islands of Micronesia (northwest Pacific Ocean) have a history at least one millennium long of coping with sea-level change (Nunn et al., 2017). Their society is organised to meet such challenges, their knowledge about the efficacy of particular adaptive solutions in particular situations is well honed - both cultural attributes that should be embraced (not overlooked) in the development of plans for coping with the effects of future climate change. Similar suggestions have been made for other island societies (McNamara, 2013, McMillen et al., 2014, Duvat et al., 2017) which are likely to be disproportionately impacted by $21^{\text {st }}$-century climate change.

Understanding how people in the past viewed the 'end of the world', how they conceived and responded to the associated threats, and how they eventually survived it are all legitimate topics of relevance to the future. It can be concluded that adaptation to the threats of future climate change is insufficient and that, in consequence, there will be a number of avoidable environmental shocks in the future. Teaching people that their ancestors overcame such shocks in the past is certain to help dispel any notion that we are today (again) looking at the end of the world.

\section{Aknowledgements}

I am grateful to Frédéric Le Blay, Rita Compatangelo-Soussignan, Étienne Chauveau, and the Scientific Committee of the 2016 Atlantys Conference for their gracious invitation and support to attend a first-rate meeting.

\section{References}

Baltzer A., Cassen S., Walter-Simonnet A.V., Clouet H., Lorin A., Tessier B., 2015. Variations du niveau marin Holocène en Baie de Quiberon (Bretagne sud): marqueurs archéologiques et sédimentologiques. Quaternaire, $\mathrm{n}^{\circ} 26$, vol. 2, p. 105-115.

Barber E.W., Barber P.T., 2004. When They Severed Earth from Sky: How the Human Mind Shapes Myth. Princeton, Princeton University Press.
Barker D.C., Bearce D.H., 2013. End-times theology, the shadow of the future, and public resistance to addressing global climate change. Political Research Quarterly, n 66 , vol. 2, p. 267-279. doi: 10.1177/1065912912442243.

Bennett N.J., Dearden P., Murray G., Kadfak A., 2014. The capacity to adapt?: communities in a changing climate, environment, and economy on the northern Andaman coast of Thailand. Ecology and Society, $\mathrm{n}^{\circ}$ 19, vol. 2, p. \#5. doi: 10.5751/es-06315-190205.

Billard C., Daire M.-Y., Martin C., 2016. Un premier inventaire des sites préhistoriques submergés au large des côtes Françaises Bulletin de l'A.M.A.R.A.I., nº 29, vol., p. 5-49.

Bird M.I., Fifield L.K., Teh T.S., Chang C.H., Shirlaw N., LAмвеск K., 2007. An inflection in the rate of early midHolocene eustatic sea-level rise: a new sea-level curve from Singapore. Estuarine, Coastal and Shelf Science, $\mathrm{n}^{\circ} 71$, vol. 3-4, p. 523-536. doi: 10.1016/j.ecss.2006.07.004.

Bruckner H., Kelterbaum D., Marunchak O., Porotov A., Vотт A., 2010. The Holocene sea level story since 7500 BP - lessons from the Eastern Mediterranean, the Black and the Azov Seas. Quaternary International, n 225, vol. 2, p. 160-179. doi: 10.1016/j.quaint.2008.11.016.

Buchs M., Hinton E., Sмiтh G., 2015. It helped me sort of face the end of the world': the role of emotions for third sector climate change engagement initiatives. Environmental Values, no 24, vol. 5, p. 621-640. doi: 10.3197/0963271 $15 \times 14384223590177$.

Cane S., 2002. Pila Nguru: The Spinifex People. North Fremantle, Western Australia: Fremantle Arts Centre Press.

Cassen S., 2009. Exercice de Stèle: Une Archéologie des Pierres Dressées, Réflexion autour des Menhirs de Carnac. Paris, Errance.

Cassen S., Baltzer A., Lorin A., Fournier J., Sellier D., 2011. Submarine Neolithic stone rows near Carnac (Morbihan), France: preliminary results from acoustic and underwater survey. in Benjamin J., Bonsall C., Pickard C., Fischer A. (dir.), Submerged Prehistory, Oxford, Oxbow Books, p. 99-110.

Cassen S., Grimaud V., Lescop L., Paitier H., 2018. The 'historiated' Neolithic stele of Saint-Samson-sur-Rance (Côtesd'Armor, France). Cambridge Archaeological Journal, n 28, vol. 2, p. 259-281.

Church J.A., Clark P.U., Cazenave A., Gregory J.M., Jevrejeva S., Levermann A., Merrifield M.A., Milne G.A., Nerem R.S., Nunn P.D., Payne A.J., Pfeffer W.T., Stammer D., Unnikrishnan A.S., 2013. Sea level change. in Stocker T.F., Qin D., Plattner G.-K., Tignor M., Allen S.K., Boschung J., Nauels A., XIA Y., Bex V., Midgley P.M. (dir.), Climate Change 2013: The Physical Science Basis. Working Group I Contribution to the Fifth Assessment Report of the Intergovernmental Panel on Climate Change, Cambridge, Cambridge University Press, p. 1137-1308.

Currey B., 1980. Famine in the Pacific: losing the chances for change. GeoJournal, $\mathrm{n}^{\circ}$ 4, vol. 5, p. 447-466.

Dangendorf S., Marcos M., Woppelmannc G., Conrad C.P., Frederikse T., Riva R., 2017. Reassessment of 20th century global mean sea level rise. Proceedings of the Natio- 
nal Academy of Sciences of the United States of America, $\mathrm{n}^{\circ}$ 114, vol. 23, p. 5946-5951. doi: 10.1073/pnas.1616007114.

Day J.W. Jr., Gunn J.D., Folan W.J., Yáñez-Arancibia A., Horton B.P., 2007. Emergence of complex societies after sea level stabilized. Eos Trans. AGU, no 88, vol. 15, p. doi: 10.1029/2007eo150001.

Dixon R.M.W., 1980. The Languages of Australia. Cambridge, Cambridge University Press.

DoAn J., 1981. The legend of the sunken city in Welsh and Breton tradition. Folklore, no 92, vol. i, p. 77-83.

Draper N., 2015. Islands of the dead? Prehistoric occupation of Kangaroo Island and other southern offshore islands and watercraft use by Aboriginal Australians. Quaternary International, no 385, vol., p. 229-242. doi: dx.doi.org/10.1016/j. quaint.2015.01.008.

Dundes A. (dir.), 1988. The Flood Myth. Berkeley: University of California Press.

Duvat V.K.E., Magnan A.K., Wise R.M., Hay J.E., Fazey I., Hinkel J., Stojanovic T., Yamano H., Ballu V., 2017. Trajectories of exposure and vulnerability of small islands to climate change. Wiley Interdisciplinary Reviews-Climate Change, $\mathrm{n}^{\circ}$ 8, vol. 6, p. UNSP e478. doi: 10.1002/wcc.478.

FLood J., 2006. The Original Australians: Story of the Aboriginal People. Crows Nest, Allen and Unwin.

Goslin J., Lanoe B.V.V., Spada G., Bradley S., Tarasov L., Neill S., SuAnez S., 2015. A new Holocene relative sealevel curve for western Brittany (France): insights on isostatic dynamics along the Atlantic coasts of north-western Europe. Quaternary Science Reviews, no 129, vol., p. 341365. doi: 10.1016/j.quascirev.2015.10.029.

Gribble E.R.B., 1932. The Australian Aboriginal. Sydney: Angus and Robinson.

Guyot C., 1979. The Legend of the City of Ys. Translated by Cavanagh, D. Amherst, University of Massachusetts Press.

Haberle S.G., Chepstow-Lusty A., 2000. Can climate influence cultural development? A view through time. Environment and History, ${ }^{\circ}$ 6, vol. 2000, p. 349-369.

Huggett R.J., 1989. Cataclysms and Earth History: The Development of Diluvialism. Oxford: Clarendon Press.

IPCC, 2014. Climate Change 2014: Synthesis Report. Contribution of Working Groups I, II and III to the Fifth Assessment Report of the Intergovernmental Panel on Climate Change [Core Writing Team, R.K. Pachauri and L.A. Meyer (eds.)]. Geneva, IPCC.

ЈАсов К.Н., 2015. Sea level rise, storm risk, denial, and the future of coastal cities. Bulletin of the Atomic Scientists, $\mathrm{n}^{\circ}$ 71, vol. 5, p. 40-50. doi: 10.1177/0096340215599777.

Janif S., Nunn P.D., Geraghty P., Aalbersberg W., Thomas F.R., Camailakeba M., 2016. Value of traditional oral narratives in building climate-change resilience: insights from rural communities in Fiji. Ecology and Society, n ${ }^{\circ} 21$, vol. 2, p. \#7. doi: 10.5751/ES-08100-210207.

Jevrejeva S., Grinsted A., Moore J.C., 2014. Upper limit for sea level projections by 2100 . Environmental Research Letters, no 9, vol. 10, p. \#104008. doi: 10.1088/17489326/9/10/104008.
Kench P.S., Smithers S.G., McLean R.F., Nichol S.L., 2009. Holocene reef growth in the Maldives: Evidence of a midHolocene sea-level highstand in the central Indian Ocean. Geology, no 37, vol. 5, p. 455-458. doi: 10.1130/g25590a.1.

LAWRY W., 1850. Friendly and Feejee Islands: A Missionary Visit. London, Charles Gilpin.

Lewis S.E., Sloss C.R., Murray-Wallace C.V., Woodroffe C.D., Smithers S.G., 2013. Post-glacial sea-level changes around the Australian margin: a review. Quaternary Science Reviews, no 74, p. 115-138. doi: 10.1016/j.quascirev.2012.09.006.

McMillen H.L., Ticktin T., Friedlander A., Jupiter S.D., Thaman R., Campbell J., Veitayaki J., Giambelluca T., Nihmei S., Rupeni E., Apis-Overhoff L., AalbersBerg W., Orcherton D.F., 2014. Small islands, valuable insights: systems of customary resource use and resilience to climate change in the Pacific. Ecology and Society, $\mathrm{n}^{\circ}$ 19, vol. 4, p. \#44. doi: 10.5751/ES-06937-190444.

McNamara K.E., 2013. Raising awareness about climate change in Pacific communities. Environmental Education Research, $\mathrm{n}^{\circ}$ 19, vol. 6, p. 864-871. doi: 10.1080/13504622.2013.769046.

McNeill J.R., 1994. Of rats and men: a synoptic environmental history of the island Pacific. Journal of World History, $\mathrm{n}^{\circ}$ 5, vol. 2, p. 299-349.

McNiven I.J., 2008. Sentient sea: seascapes as spiritscapes. in David B., Thomas J. (dir.), Handbook of Landscape Archaeology, Walnut Creek: Left Coast Press, p. 149-157.

Mimura N., 2013. Sea-level rise caused by climate change and its implications for society. Proceedings of the Japan Academy Series B-Physical and Biological Sciences, n 89, vol. 7, p. 281-301. doi: 10.2183/pjab.89.281.

Nunn P.D., 2007. Climate, Environment and Society in the Pacific during the Last Millennium. Amsterdam, Elsevier.

Nunn P.D., 2018a. The Edge of Memory: Ancient Stories, Oral Tradition and the Post-Glacial World. London, Bloomsbury Sigma.

Nunn P.D., 2018b. The Edge of Memory: Recollections of Coastal Drowning and Other Observations over 7000 Years Ago. London, Bloomsbury.

Nunn P.D., Reid N.J., 2016. Aboriginal memories of inundation of the Australian coast dating from more than 7000 years ago. Australian Geographer, n 47, vol. 1, p. 11-47. doi: 10.1080/00049182.2015.1077539.

Nunn P.D., Runman J., Falanruw M., Kumar R., 2017. Culturally grounded responses to coastal change on islands in the Federated States of Micronesia, northwest Pacific Ocean. Regional Environmental Change, no 17, vol. 4, p. 959-971. doi: 10.1007/s10113-016-0950-2.

Roberts M.J., Scourse J.D., Bennell J.D., Huws D.G., Jago C.F., Long B.T., 2011. Late Devensian and Holocene relative sea-level change in North Wales, UK. Journal of Quaternary Science, n ${ }^{\circ}$ 26, vol. 2, p. 141-155. doi: 10.1002/ jqs. 1443.

Rowland M.J., Wright S., Baker R., 2015. The timing and use of offshore islands in the Great Barrier Reef Marine Province, Queensland. Quaternary International, $\mathrm{n}^{\circ}$ 
385, vol. 22 October 2015, p. 154-165. doi: 10.1016/j. quaint.2015.01.025.

Schlehe J., 2008. Cultural politics of natural disasters: discourses on volcanic eruptions in Indonesia. in CASImir M.J. (dir.), Culture and the Changing Environment: Uncertainty, Cognition, and Risk Management in Cross-cultural Perspective, Oxford: Berghahn, p. 275-299.

SÉвillot P., 1899. Légendes Locales de la Haute-Bretagne. Nantes: Société des Bibliophiles Bretons.

SEVERN R., 2012. Understanding earthquakes: from myth to science. Bulletin of Earthquake Engineering, ${ }^{\circ}$ 10, vol. 2, p. 351-366.

Sim R., West D., 1998. Prehistoric human occupation in the Bass Strait region: an Aboriginal and archaeological perspective. in Uско P.J., Layton R. (dir.), Archaeology and Anthropology of Landscape: Shaping Your Landscape, London: Routledge, p. 424-439.

Torngvist T.E., Bick S.J., Gonzalez J.L., van der Borg K., DE Jong A.F.M., 2004. Tracking the sea-level signature of the 8.2 ka cooling event: new constraints from the Missis- sippi Delta. Geophysical Research Letters, no 31, vol. 23, p. \#L23309. doi: 10.1029/2004gl021429.

Turney C.S.M., Brown H., 2007. Catastrophic early Holocene sea level rise, human migration and the Neolithic transition in Europe. Quaternary Science Reviews, n 26, vol. 17-18, p. 2036-2041. doi: 10.1016/j.quascirev.2007.07.003.

Vitaliano D., 1973. Legends of the Earth: their Geologic Origins. Bloomington, Indiana, Indiana University Press.

Wојсік D., 1996. Embracing Doomsday + Millennialism, religion, folklore: Faith, fatalism, and apocalyptic beliefs in the nuclear age. Western Folklore, no 55, vol. 4, p. 297-330. doi: 10.2307/1500138.

Woodroffe S., Horton B., 2005. Holocene sea-level changes in the Indo-Pacific. Journal of Asian Earth Sciences, $\mathrm{n}^{\circ} 25$, vol. 1, p. 29-43. doi: 10.1016/j.jseaes.2004.01.009.

Ziauddin S.B., 2017. (De)territorializing the home. The nuclear bomb shelter as a malleable site of passage. Environment and Planning D-Society E Space, $\mathrm{n}^{\circ}$ 35, vol. 4, p. 674-693. doi: $10.1177 / 0263775816677551$. 